\title{
PENERAPAN RAGAM HIAS MINANGKABAU DALAM PEMBELAJARAN MEMBATIK BAGI GURU SENI BUDAYA SMPN DAN MTsN KABUPATEN PADANG PARIAMAN
}

\author{
Syafei $^{1^{*}}$, Efrizal $^{2 *}$, Yasrul Sami $^{3^{*}}$, Zubaidah $^{4 *}$, Ariusmedi $^{5^{*}}$, Maltha Kharisma $^{6^{*}}$ \\ Jurusan Seni Rupa Fakultas Bahasa dan Seni \\ Universitas Negeri Padang \\ Jl. Prof. Dr. Hamka, Air Tawar Padang, Kel. Air Tawar Barat, Kec. Padang Utara, Kota Padang, Kode Pos 25132 \\ Sumatera Barat. Indonesia \\ Email: syafei.saf@gmail.com
}

\begin{abstract}
Abstrak
Salah satu kendala dalam meningkatkan kualitas pendidikan dan pembelajaran di sekolah-sekolah adalah kurangnya perbaikan terhadap kualitas guru. Di samping itu keterbatasan kesempatan untuk mendapatkan penambahan ilmu dan keterampilan bagi guru menjadi penyebab turunnya mutu pendidikan. Hasil diskusi tim instruktur dengan Desmiyanti, S,Pd. guru bidang Studi Seni Rupa SMPN 2 VII Koto Sungai Sariak Kabupaten Padang Pariaman (2020) bahwa: pelaksanaan pembelajaran Seni Rupa di SMPN Kabupaten Padang Pariaman rata-rata diajar oleh guru-guru dengan latar belakang pendidikan bukan Seni Rupa. Salah satu indikasi menunjukkan rendahnya kemampuan guru dalam materi pembelajaran membatik yang membutuhkan teori dan praktik bahan dan peralatan serta perosedur yang baku. Konsekuensinya, pembelajaran seni rupa khususnya materi membatik tidak berjalan menurut semestinya. Apalagi jika dikaitkan dengan bahan dan peralatan membatik yang ratarata sekolah tingkat SMP sudah mendapatkan subsidi dari dinas pendidikan. Namun kenyataannya, guru tidak mampu memanfaatkan bahan dan peralatan membatik yang sudah tersedia untuk pembelajaran seni rupa. Kekhawatiran terhadap ketidakmampuan guru dalam proses pembelajaran khususnya materi membatik ini, mengharuskan guru mengikuti pendidikan dan pelatihan/ workshop tentang: "Penerapan Ragam Hias Minangkabau dalam Pembelajaran Membatik bagi Guru-Guru Seni Budaya SMP dan MTsN di Kabupaten Padang Pariaman”, sehingga guru seni budaya SMP/MTsN mampu mengajarkan salah satu Standar Kompetensi yaitu: (4.1) "penerapan Ragam Hias pada tekstil basis kain” di kelas VII.
\end{abstract}

Kata Kunci: seni budaya, membatik.

\begin{abstract}
One of the obstacles in improving the quality of education and learning in schools is the lack of improvement in the quality of teachers. In addition, the limited opportunity to gain additional knowledge and skills for teachers is the cause of the decline in the quality of education. The results of the instructor team's discussion with Desmiyanti, S, Pd. a teacher in the field of Fine Arts Studies at SMPN 2 VII Koto Sungai Sariak, Padang Pariaman Regency (2020) that: the implementation of Fine Arts learning at SMPN Padang Pariaman Regency is on average taught by teachers with educational backgrounds other than Fine Arts. One indication shows the low ability of teachers in batik learning materials that require theory and practice of standard materials and equipment and procedures. As a consequence, the learning of fine arts, especially batik material, does not work properly. Especially if it is related to batik materials and equipment, the average junior high school level has received subsidies from the education office. However, in reality, teachers are not able to utilize the materials and equipment of batik that are already available for learning fine arts. Concerns about the inability of teachers in the learning process, especially this batik material, require teachers to attend education and training/workshops on: "The Application of Minangkabau Ornaments in Batik Learning for Middle School and MTsN Cultural Arts Teachers in Padang Pariaman Regency", so that junior high school arts and culture teachers /MTsN is able to teach one of the Competency Standards, namely: (4.1) "application of Decorative Variety on textiles based on fabrics" in class VII.
\end{abstract}

Keywords: art and culture, membatik. 
Gorga : Jurnal Seni Rupa

Volume 10 Nomor 02 Juli-Desember 2021

p-ISSN: 2301-5942 | e-ISSN: 2580-2380

\section{PENDAHULUAN}

Mata pelajaran Seni Budaya di tingkat Sekolah Menengah Pertama (SMP) merupakan kajian yang memberikan pengetahuan Seni Rupa dalam membuat suatu karya yang berfungsi untuk mengembangkan kreatifitas, sikap produktif, mandiri dan mengembangkan sikap menghargai berbagai cabang Seni Rupa dan hasil karya. Pembelajaran Seni Rupa diberikan kepada siswa berupa teori tentang pengertian, jenis, fungsi, bahan dan teknik membuat karya yang diajarkan mulai dari membuat desain, proses membuat karya sampai pada tahap berpameran karya. Manfaat Seni Rupa ini dapat mengembangkan sikap kreatif dan mandiri siswa sehingga mampu beradaptasi dengan perkembangan ilmu pengetahuan dan teknologi.

Usaha meningkatkan pengetahuan Seni Rupa siswa dimulai sedini mungkin melalui pembelajaran di sekolah karena tidak semua lulusan SMP/MTs dapat melanjutkan pendidikan ke jenjang yang lebih tinggi. Bagi siswa yang tidak mampu melanjutkan pendidikannya ke jenjang yang lebih tinggi, diharapkan memiliki keterampilan yang memadai agar siap bekerja pada suatu wadah sesuai dengan bidang yang ditekuni. Oleh sebab itu pelajaran seni rupa perlu diberikan pada tingkat SMP atau MTs.

Begitu juga dengan guru, keprofesionalan seorang guru seni rupa adalah harus mampu menunjukkan kinerjanya dalam melaksanakan tugas profesi kependidikan yang ditandai dengan penguasan kompetensi akademik kependidikan dan penguasaan kompetensi substansi dan/atau bidang studi sesuai bidang ilmunya. Salah satu contoh adalah guru seni rupa tidak hanya profesional di bidang kesenirupaan tetapi harus menguasai substansi bidang keterampilan lainnya. Asumsi ini didasari atas standar kompetensi yang harus diajarkan guru seni rupa pada tingkat satuan pendidikan Sekolah Menengah Pertama (SMP).

Bertolak dari hasil pengamatan dan diskusi tim instruktur pelatihan dengan guru bidang studi Seni Rupa di beberapa SMP Padang Pariaman (12 Desember 2020) bahwa, sebahagian besar guru belum mampu mengajarkan pembelajaran seni rupa khususnya materi membatik karena membutuhkan aspek teori bahan dan praktik membatik. Artinya, tuntutan standar kompetensi khususnya pembelajaran Seni Rupa yaitu “(4.1) "penerapan Ragam Hias pada Tekstil basis kain" di kelas VII, tidak berjalan menurut semestinya. Berdasarkan temuan di salah satu sekolah, bahwa bahan dan perlengkapan membatik sudah ada subsidi dari dinas pendidikan untuk semua SMP di Kabupaten Padang Pariaman. Tentu hal ini menimbulkan masalah karena tidak sejalan antara bahan dan peralatan membatik yang sudah tersedia dengan kemampuan guru seni rupa untuk mengajarkannya. Penyebab masalah ini adalah 1) latar belakang pendidikan guru bukan seni rupa atau seni budaya. 2) guru lebih mendominasikan pembelajaran seni rupa aspek apresiasi, 3) kebanyakkan guru tidak memiliki kemampuan mengajar di bidang membatik. Hal ini tentunya secara langsung akan berdampak pada tidak adanya wawasan dan keterampilan yang dimiliki siswa setelah tamat Sekolah Menengah Pertama. Diketahui bahwa tidak semua siswa dapat melanjutkan pendidikan ke jenjang yang lebih tinggi dengan berbagai faktor. Maka, konsekwensinya, siswa tidak dapat hidup mandiri karena tidak memiliki keterampilan yang dapat dikembangkan sebagai bidang usaha.

Menghadapi situasi ini, guru pendidik seni rupa di SMP/MTs harus memiliki pengetahuan/wawasan seni rupa khusus materi membatik. Di samping itu, sebagai guru seni budaya juga harus memiliki kejelian untuk memilih pendekatan yang dapat mengajak semua siswa untuk berpartisipasi aktif dalam pembelajaran Seni Rupa. Sekaligus juga harus dapat mendorong siswa agar mampu meningkatkan kemampuan mencetuskan imajinasi dan gagasan ke dalam bentuk kegiatan berkarya Seni Rupa sesuai dengan kompetensi dasar yang sudah ditetapkan.

Di tengah-tengah keprihatinan terhadap kekurangmampuan guru dalam pembelajaran membatik, maka tim pengabdian kepada masyarakat mencari beberapa referensi informasi tentang pendekatan pembelajaran yang dapat dipertanggungjawabkan. Untuk itu tim intruktur mencoba memberikan pengetahuan pada standar kompetensi: "penerapan Ragam Hias pada Tekstil basis kain" di kelas VII" kepada guru-guru seni budaya SMP/MTs Kabupaten Padang Pariaman dengan judul: Pelatihan Penerapan Ragam Hias Minangkabau dalam Pembelajaran Membatik Bagi Guru Seni Budaya SMP/MTs Kabupaten Padang Pariaman. Konsep kegiatan pelatihan ini didasari atas : a) kelangkaan buku teks bidang membatik sebagai buku acuan wajib bagi guru seni budaya, b) membekali para guru dengan berbagai pengetahuan dan keterampilan membatik, diyakini akan lebih efektif dan efisien, sehingga sasaran yang diharapkan dapat tercapai secara maksimal. 


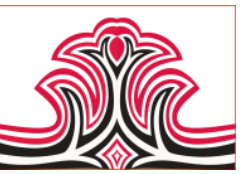

KAJIAN TEORI

\section{Ragam Hias}

Ragam hias ukiran Minangkabau ini pada umumnya diterapkan pada bangunan seperti rumah gadang atau rumah adat, istana kerajaan, balai adat, masjid, rangkiang, dan lain-lain, baik untuk bidang kecil maupun pada bidang besar. Selain itu juga diterapkan pada beberapa peralatan sehari-hari misalnya pada peralatan upacara, rumah tangga, alat pertanian, alat permainan dan sebagainya (Khairuzzaky, 2018).

\section{Minangkabau}

Masyarakat Minangkabau berlokasi di bagian barat pulau Sumatra, sebagian mendiami wilayah daerah pesisir baratSumatra Utara, sebagian daerah propinsi Riau bagian barat, dan sebagian daerah propinsi Jambi bagian barat daya. Dari cakupan wilayah yang didiami oleh suku bangsa Minangkabau tersebut, sebagian besar menempati wilayah daratan. Karena itulah, Arsitektur Nusantara Minangkabau dikatakan sebagai arsitektur nusantara daratan (Ninka dalam Prasetya, 2008: 59).

\section{METODE PENELITIAN}

Pengumpulan data pada sebuah penelitian, terkadang menemui kendala saat peneliti memerlukan data dengan karakteristik khusus, misalnya tentang persepsi, opini, kepercayaan dan sikap terhadap suatu produk, pelayanan, konsep atau ide. Begitu pula untuk penelitian dengan tujuan tertentu, misalnya kajian kebutuhan atau evaluasi suatu program. Untuk itu diperlukan suatu teknik pengumpulan data di mana partisipan dibebaskan untuk saling berdiskusi tanpa ada rasa takut atau kuatir terhadap pendapat yang akan dikeluarkannya. Salah satu teknik pengumpulan data yang cocok dalam hal ini adalah teknik Focus Group Discussion $(F G D)$ atau Diskusi Kelompok Terarah.

\section{HASIL DAN PEMBAHASAN}

\section{Hasil}

Bertolak dari permasalahan yang dihadapi guru-guru Seni Budaya SMP se Kabupaten Padang Pariaman khususnya dalam pembelajaran membatik, maka diperlukan solusi yang tepat untuk mengatasinya yakni melalui pelatihan. Metode pendekatan yang ditawarkan untuk mendukung realisasi program pelatihan ini adalah rancang bangun, penyuluhan, pelatihan dan pendampingan. Agar realisasi metode yang ditawarkan dapat terlaksana dengan baik dan tujuan tercapai secara maksimal, maka dilakukan prosedur kerja sebagai berikut.
Gorga : Jurnal Seni Rupa

Volume 10 Nomor 02 Juli-Desember 2021 p-ISSN: 2301-5942 | e-ISSN: 2580-2380

Membagikan variasi motif ukir tradisional Minangkabau yang dapat diterapkan pada kriya batik kepada peserta sebagai acuan bagi peserta dalam merancang motif untuk kriya batik selama kegiatan pelatihan. Kaluak-paku atau relung pakis ini merupakan gulungan pucuk pakis yang masih sangat muda. Pakis merupakan tanaman yang banyak terdapat di lading atau pekarangan dan tumbuhnya sangat mudah sekali. Pucuk pakis banyak dimakan misalnya untuk digulai.

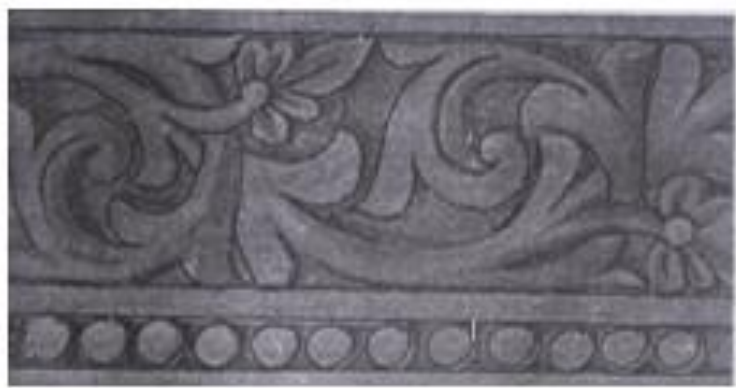

Gambar 1. Motif Ukir Minangkabau Kaluak Paku Asli (Efrizal. 1990: 35)

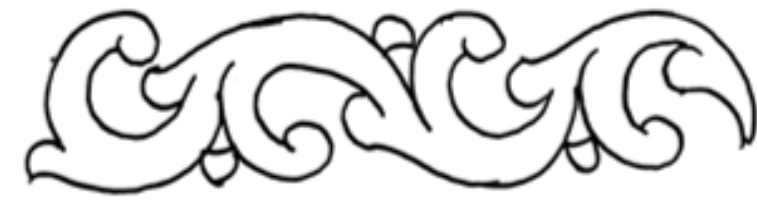

Gambar 2. Motif Kaluak Paku Penyederhanaan

Bada adalah jenis ikan teri yang banyak hidup di laut bahagian pinggir pantai. Kehidupan ikan teri ini diumpamakan pada tingkah laku yang harus diperhatikan manusia. Ikan teri ini hidup berkelompok dan seia-sekata.

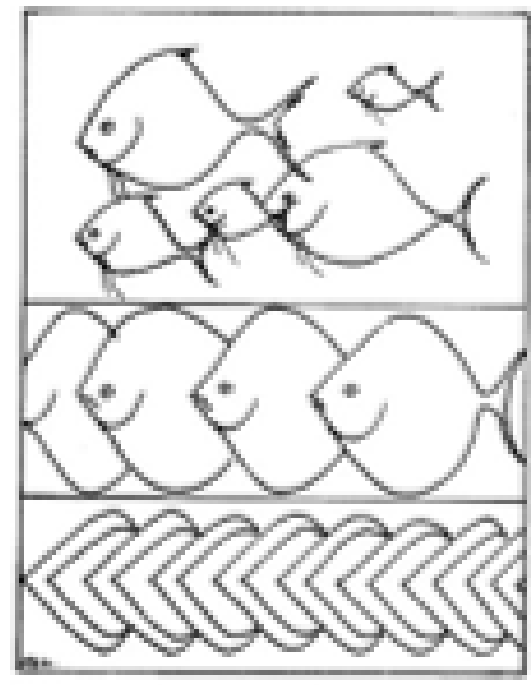

Gambar 3. Motif Bada Mudiak Asli

\section{Pembahasan \\ 1). Prosedur Kerja Pelatihan}



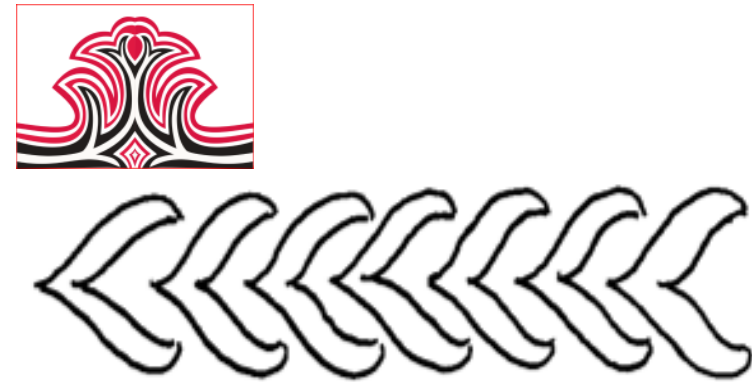

Gambar 4. Motif Bada Mudiak Penyederhanaan

Dilihat dari cara hidup itik ini, maka dapat diambil suatu tamsilan yang dalam dan perlu mendapat perhatian bagi anak kemenakan. Keseia sekataan itik ini mendapat perhatian oleh para seniman ukir Minangkabau. Itiak adalah binatang yang penurut, kemana induk rombongannya, yang dibelakang akan menurut saja. Dapat dilihat dalam kata-kata adat sebagai berikut: "Bak itiak jatuah katabiang".

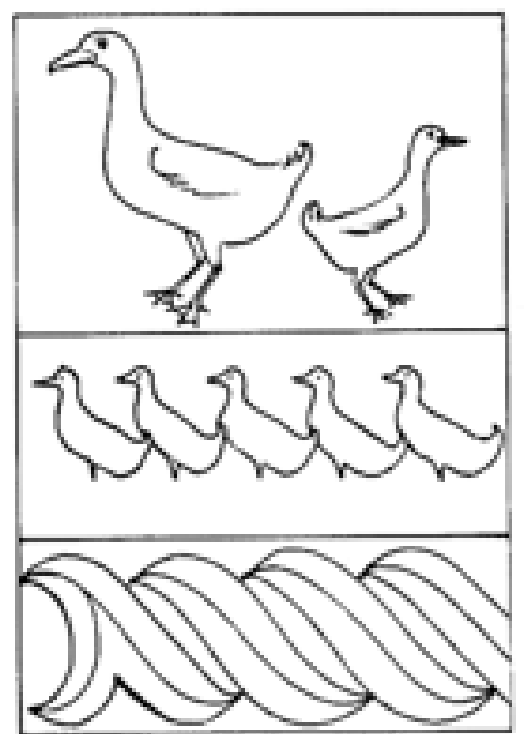

Gambar 5. Motif Itiak Pulang Patang Asli

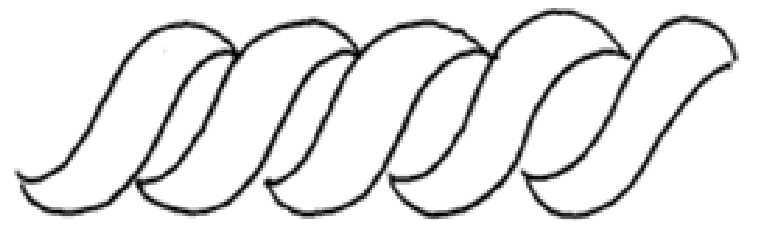

Gambar 6. Motif Itiak Pulang Patang Penyederhanaan

Dalam pepatah Minangkabau motif pucuak rabuang sebagai kiasan bahwa orang Minangkabau harus mampu mempersiapkan diri mulai dari kecil, dewasa hingga tua dalam berbagai hal agar berguna bagi orang lain, bak pepatah Minangkabau "ketek paguno, gadang tapakai artinya kecil berguna, besar terpakai.
Gorga : Jurnal Seni Rupa

Volume 10 Nomor 02 Juli-Desember 2021 p-ISSN: 2301-5942 | e-ISSN: 2580-2380

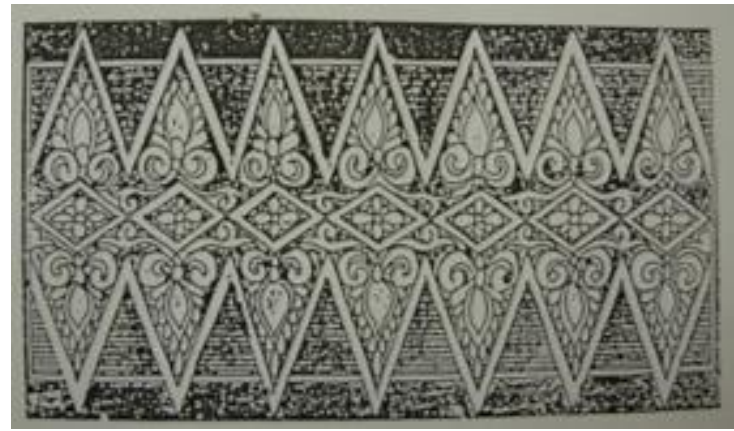

Gambar 7. Motif Pucuak Rabuang

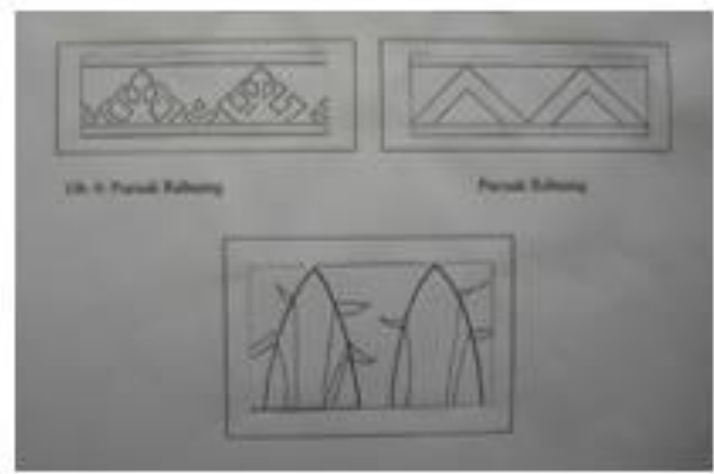

Gambar 8. Motif Pucuak Rabuang Penyederhanaan

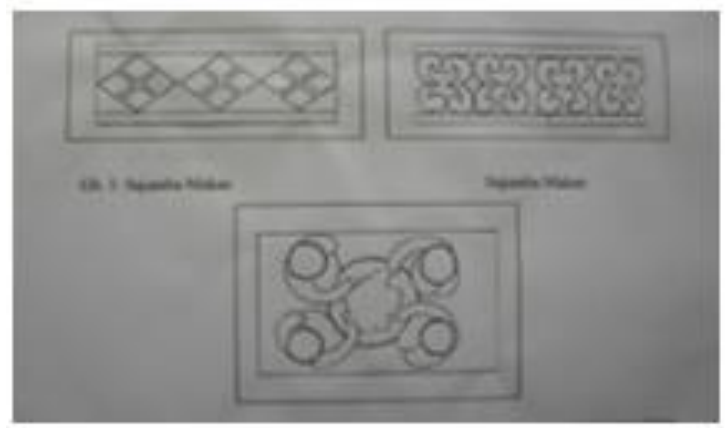

Gambar 9. Sajamba Makan

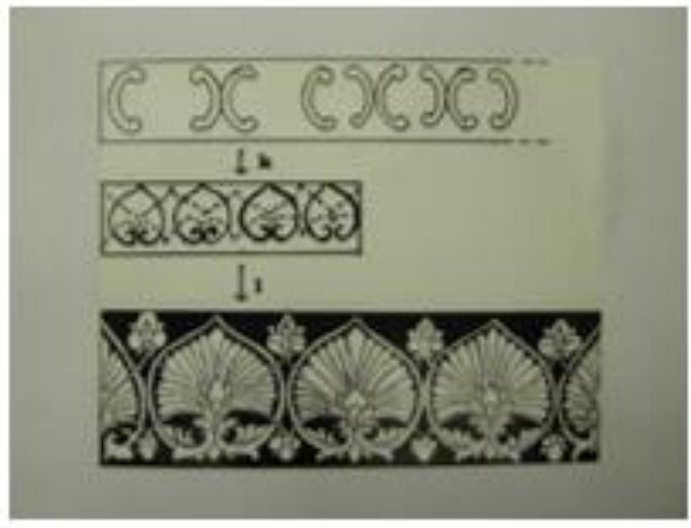

Gambar 10. Siriah Gadang

Menyajikan materi kerajinan batik dengan teknik batik tulis, dilakukan dengan metode ceramah, tanya jawab, dan demonstrasi. Agar peserta lebih memahami materi, instruktur menggunakan media power point, model/contoh karya, serta slide video proses membatik. Pelatihan berkarya kerajinan 
membatik teknik batik tulis dengan bimbingan dari instruktur.

\section{2). Metode Pendekatan yang Ditawarkan}

Metode yang ditawarkan untuk memecahkan masalah adalah dengan menerapkan teknologi kriya batik untuk menganekaragamkan jenis dan desain sebagai produk kerajinan. Agar tujuan tercapai dengan maksimal, maka beberapa metode yang digunakan adalah: a). Metode ceramah, digunakan untuk menyampaikan materi yang sifatnya teoritis., b). Metode demonstrasi, digunakan untuk memperlihatkan tentang produk-produk kriya batik serta jenis-jenisnya., c). Metode eksperimen, digunakan dalam rangka memperoleh pengalaman tentang aplikasi teknik membatik pada beberapa produk kerajinan., d). Metode pemberian tugas: digunakan untuk memantapkan penguasaan dalam menciptakan kriya batik sampai kepada Seni Budaya menempatkan motif pada sebuah produk kriya batik (benda pakai dan benda hiasan).

Aplikasi dari metode tersebut dilakukan langkahlangkah sebagai berikut yaitu: a). Pembuatan Model Minimal dibuat 3 model produk kriya batik dengan berbagai bentuk serta motif, sebagai pedoman bagi guru dalam mendesain benda kerajinan., b). Penerapan materi pelatihan pada guru Seni Budaya. Model yang dibuat dilatihkan kepada guru-guru yang dilibatkan pada pelatihan ini dengan berbagai metode, sehingga para guru dapat memahami prinsip, prosedur serta teknik dalam menciptakan kriya batik sebagai produk karya seni terapan yang harus diajarkan di SMP.

\section{3).Tahapan-Tahapan Pelaksanaan Kegiatan} Membatik

\section{(1). Tempat Kegiatan}

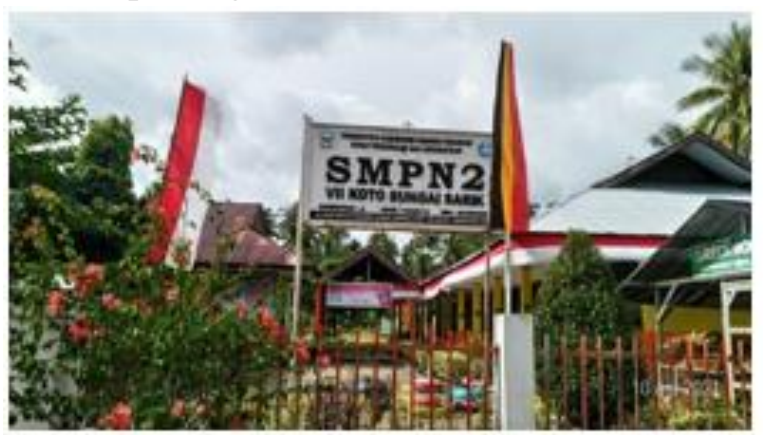

Gambar 11. Sekolah Mitra SMPN 2 VII Koto Sungai Sariak Kab. Padang Pariaman

\section{(2). Persiapan Bahan dan Peralatan}

Kain (bahan dasar untuk membatik), lilin batik (malam), lilin tembok, bahan untuk mencelup, canting tulis, kompor, wajan (kuali), dan baskom.
Gorga : Jurnal Seni Rupa

Volume 10 Nomor 02 Juli-Desember 2021 p-ISSN: 2301-5942 | e-ISSN: 2580-2380

\section{(3). Acara Pembukaan Pelatihan}

Pada tanggal 10 Agustus 2021 hari Selasa pukul 09.00 WIB telah dilaksanakan acara pembukaan Pelatihan Membatik bagi guru-guru Seni Budaya SMP Kabupaten Padang Pariaman. Acara dihadiri oleh Kepala SMPN 2 VII Koto sebagai Mitra,j para Instruktur serta guru-guru SMP yang dilibatkan sebagai peserta. Acara dibuka secara resmi oleh Kepala SMPN 2 VII Koto Dra. Yasni Tanjung, MM. Berikut foto kegiatan pembukaan acara pelatihan membatik.

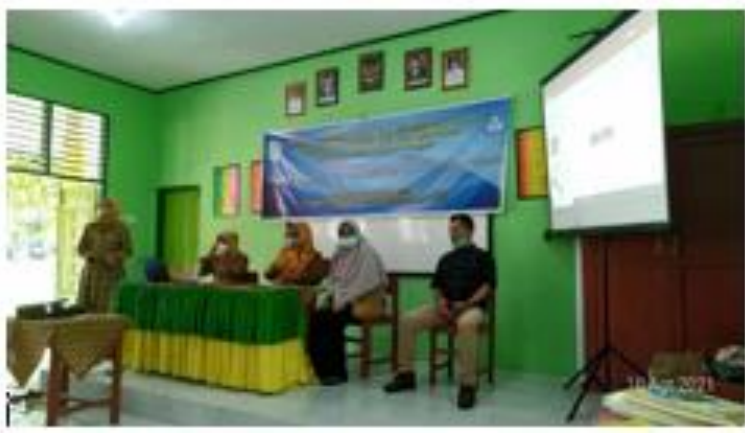

Gambar 12. Acara Pembukaan Dihadiri oleh Kepala Sekolah SMPN 2 VII Koto Sungai Sariak

\section{(4). Penyampaian Materi Pelatihan}

Sebelum latihan dilaksanakan terlebih dahulu dipersiapkan materi pelatihan berupa: 1) makalah Kerajinan Membatik, 2) model/contoh kerajinan batik, 3) bahan dan peralatan membatik 3) power point sebagai alat presentasi. Kemudian menata tempat pelatihan dengan memasang spanduk pelatihan. Adapun tahap-tahap pelaksanaan pelatihan sebagai berikut: a). Menyajikan materi; untuk memahami materi instruktur menggunakan metode ceramah, dan tanya jawab. Agar guru lebih memahami tentang materi, instruktur juga menggunakan media pembelajaran power point dan memperlihatkan model/contoh., b). Pelatihan membuat benda kerajinan batik (teknik batik tulis) dan merancang motif pada kain yang akan dibatik. Pelatihan ini dibimbing oleh instruktur dan mahasiswa.

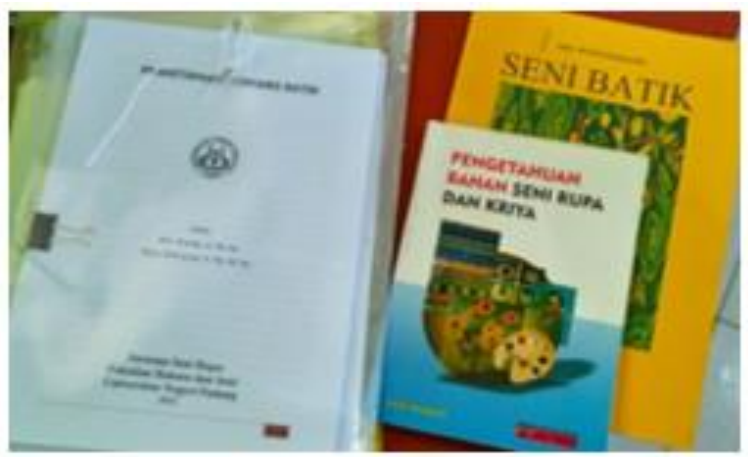

Gambar 13. Makalah utuk Peserta dan Buku Referensi tentang Seni Batik 

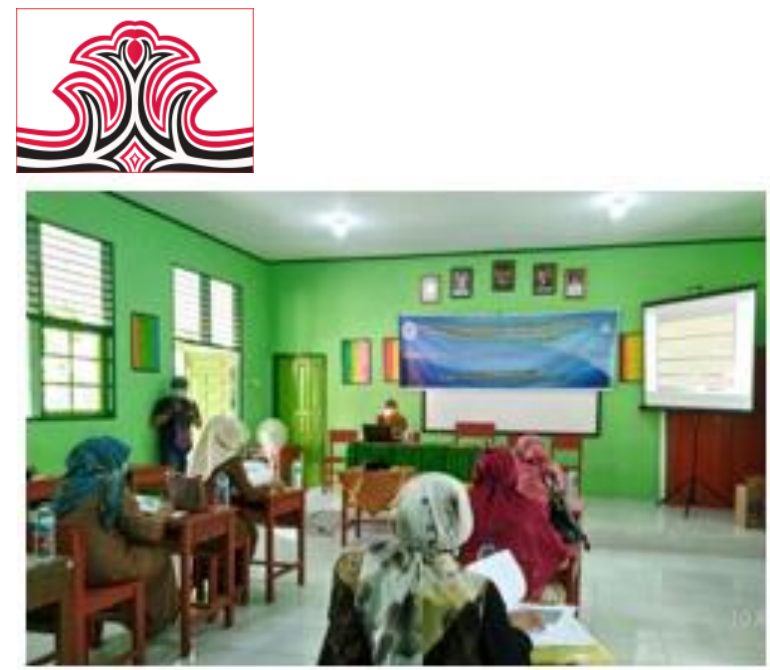

Gambar 14. Penyajian Materi Aspek Pengetahuan Kerajinan Batik Oleh Instruktur (Materi pertama)

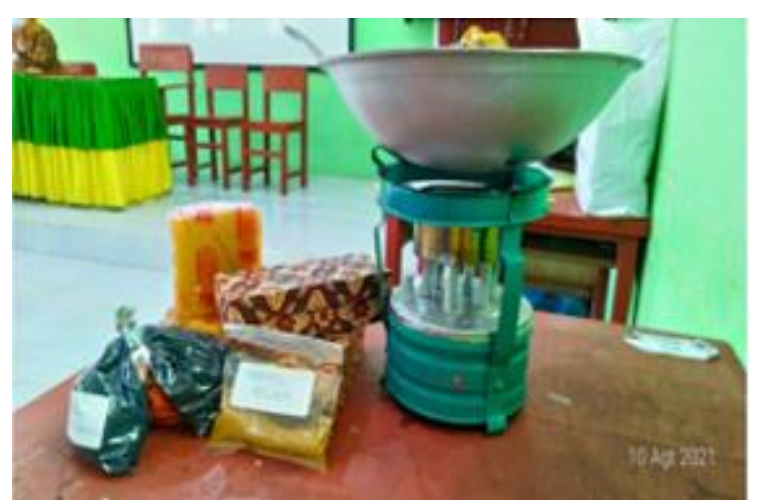

Gambar 15. Pengenalan Bahan dan Peralatan Batik kepada Peserta (Materi Kedua)

\section{(5). Gambaran Proses Membatik oleh Peserta}

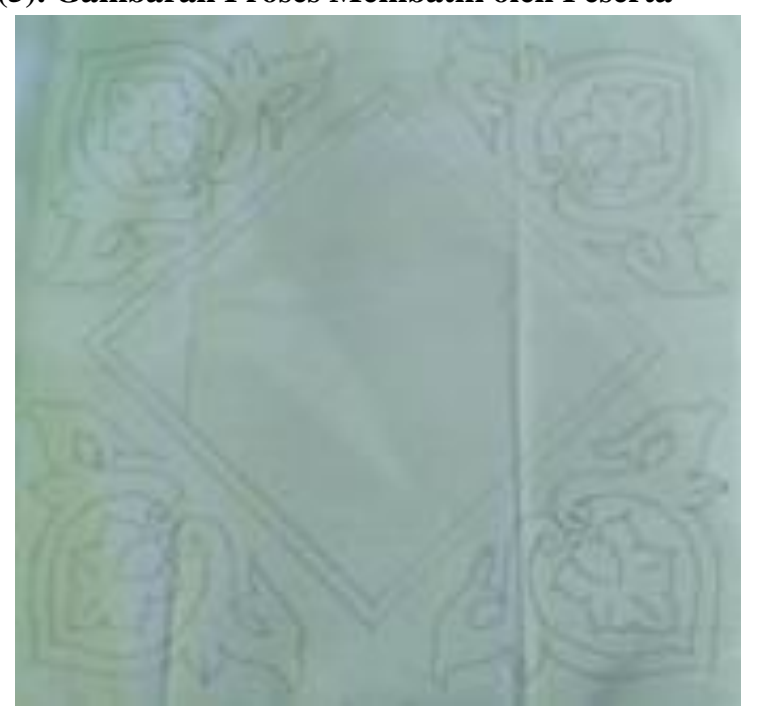

Gambar 16. Motif Siriah Gadang
Gorga : Jurnal Seni Rupa

Volume 10 Nomor 02 Juli-Desember 2021 p-ISSN: 2301-5942 | e-ISSN: 2580-2380
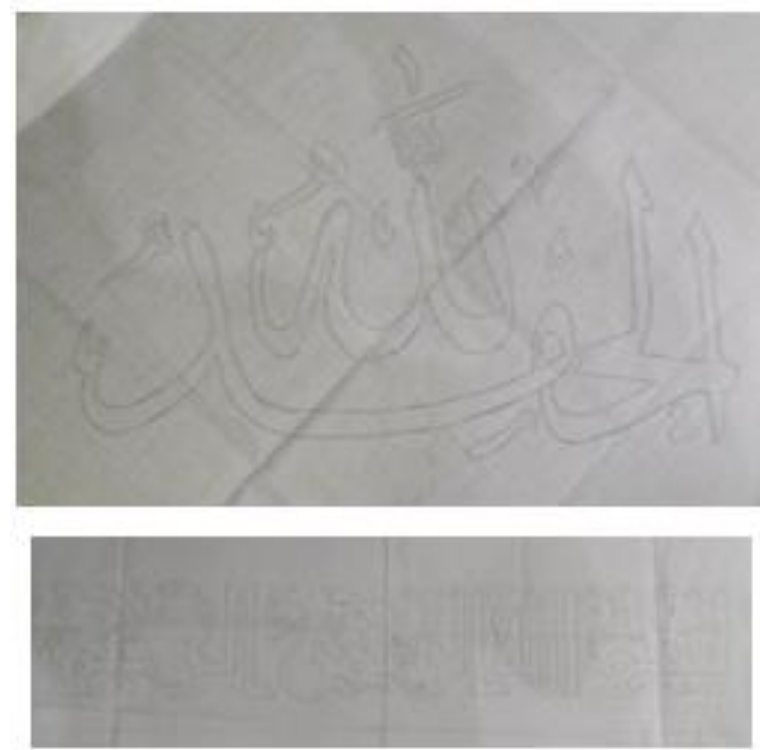

Gambar 17. Contoh Desain Kaligrafi yang akan Diaplikasikan pada Kriya Batik

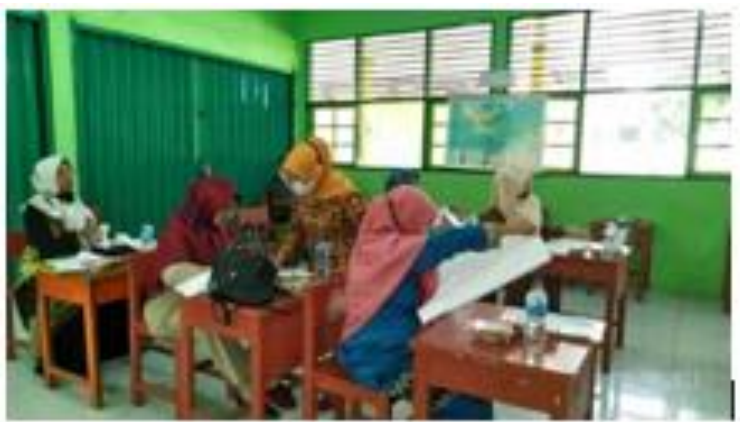

Gambar 18. Peserta Sedang Memindahkan Motif ke Bidang Kain (Proses Kedua)

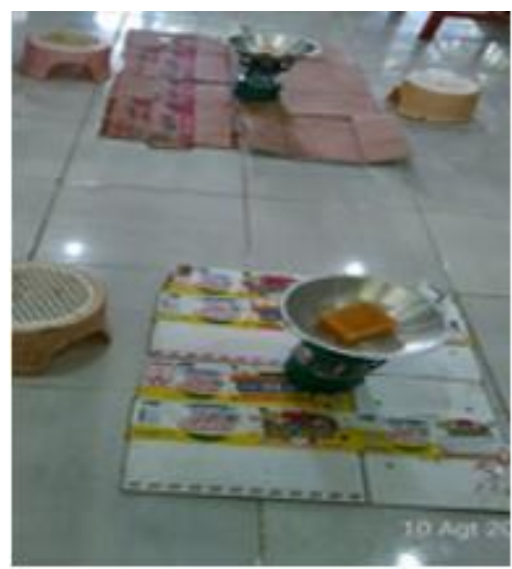

Gambar 19. Proses Memanaskan Lilin Batik Sebelum Mencanting 

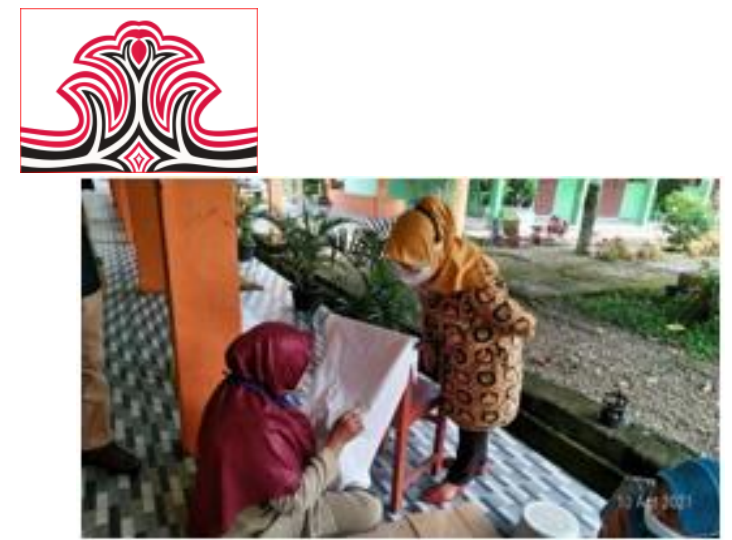

Gambar 20. Peserta Sudah Mulai Tahap Proses Mencanting (Proses Ketiga)

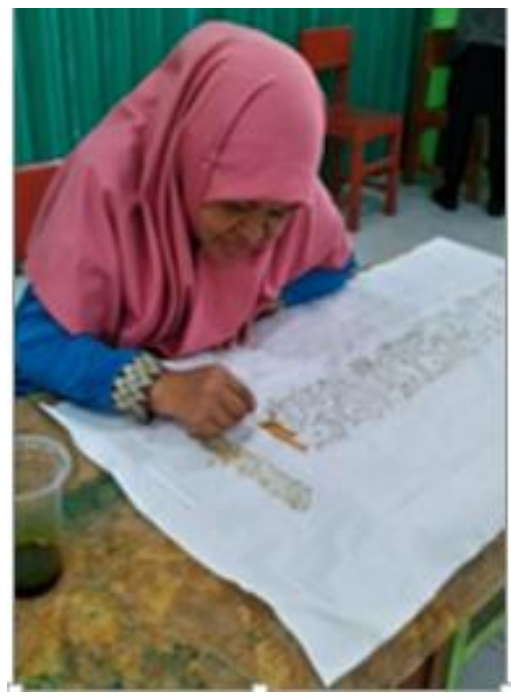

Gambar 21. Peserta Sedang Mencolet/Memberi Warna pada Motif (Proses Keempat)

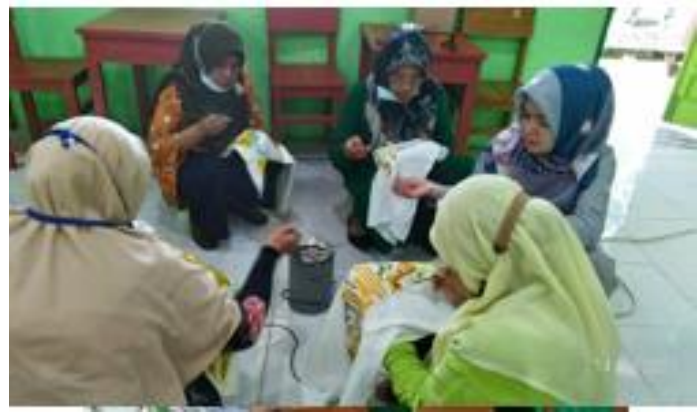

Gambar 22. Peserta sedang Proses Menembok (Proses Kelima)

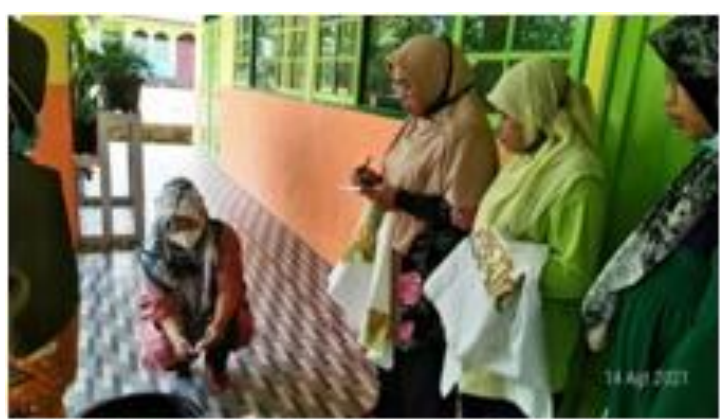

Gambar 23. Instruktur sedang Memberikan Arahan tentang Percampuran Zat Warnauntuk Mecelup Kain yang sudah Dibatik (Proses Keenam)
Gorga : Jurnal Seni Rupa

Volume 10 Nomor 02 Juli-Desember 2021 p-ISSN: 2301-5942 | e-ISSN: 2580-2380

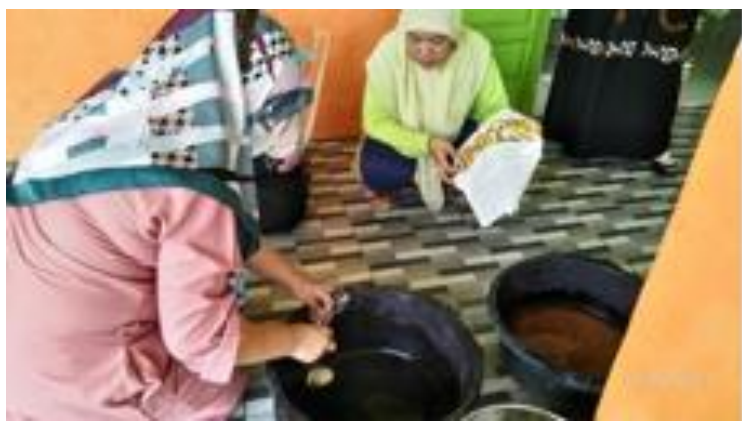

Gambar 24. Peragaan oleh Instruktur kepada Peserta saat Mencampur Warna dengan Air Mendidih untuk Persiapan Proses Mencelup Kain

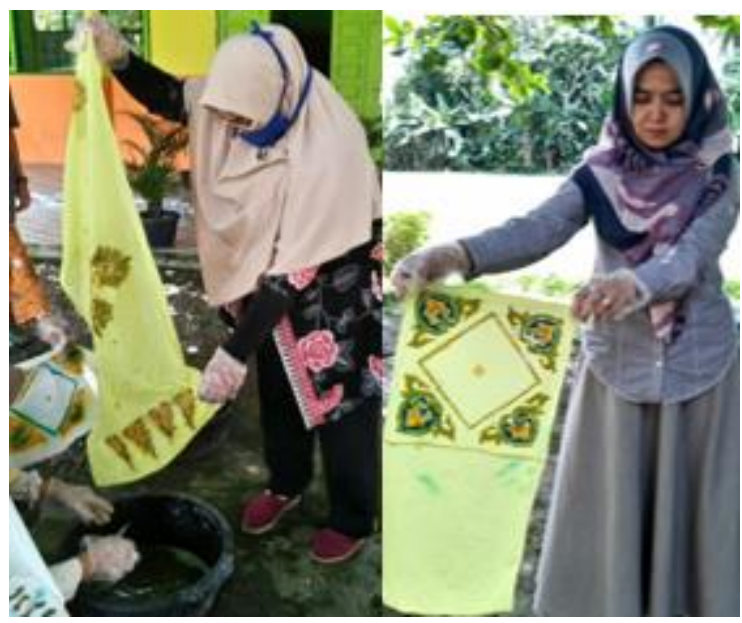

Gambar 25. Proses Merendam dengan Garam Diazhol Sebelum Mencelup (Proses Ketujuh)

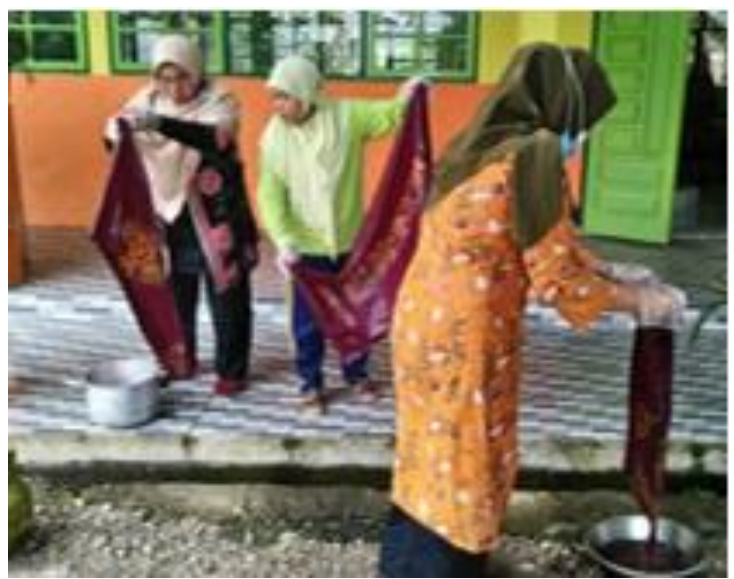

Gambar 26. Proses Mencelup Karya Batik oleh Semua Peserta (Proses Kedelapan)

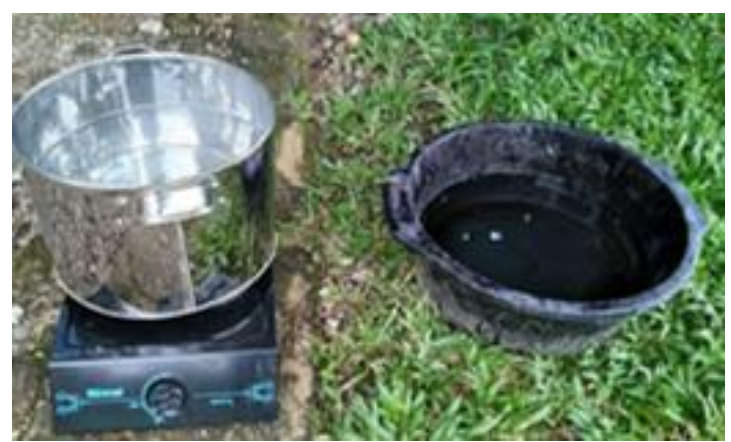

Gambar 27. Persiapan Rebusan Air untuk Proses Melorot Lilin pada Karya Batik 

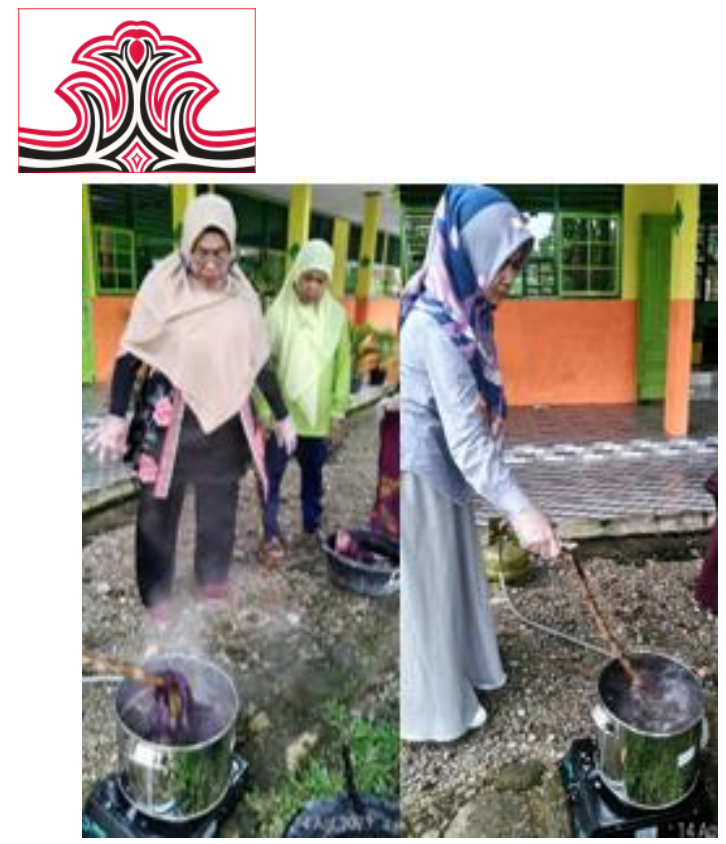

Gambar 28. Proses Melorot Lilin pada Karya Batik oleh Semua Peserta (Proses Kesembilan)

\section{KESIMPULAN DAN SARAN}

\section{Kesimpulan}

Berdasarkan hasil evaluasi yang dilakukan terhadap proses kegiatan, terlihat bahwa proses kegiatan pelatihan membatik bagi guru-guru Seni Budaya SMP sudah berjalan dengan baik. seperti: 1) semua program yang dirancang dapat dilaksanakan, tanpa ada hambatan atau kendala yang berarti, walaupun ada kendala, tetapi sudah diatasi, 2) peserta dalam mengikuti kegiatan penuh semangat dan motivasi yang tinggi. Hal ini ditandai dengan keseriusan mereka dalam kegiatan, bersemangat dalam belajar, aktif dalam bertanya, mematuhi semua petunjuk yang ada, dan mengerjakan tugas dengan serius dan tekun. Hal ini mungkin disebabkan karena materi pelatihan ini belum pernah didapatkan oleh guru-guru seni budaya SMP. Disamping itu dukungan pihak sekolah dan ketua MGMP sebagai mitra sangat besar sekali, baik dari segi memotivasi peserta maupun penyediaan fasilitas.

Hasil capaian dari kegiatan ini adalah 1) $99 \%$ peserta telah menguasai materi kerajinan batik dengan baik, begitu juga dari segi keterampilan, $95 \%$ peserta telah menguasai teknik membatik dengan baik. 2) berupa produk, yakni karya kerajinan batik berupa tempat tisu, alas meja dan hiasan dinding yang dibuat peserta. Berikut foto karya peserta sesuai desain masingmasing.

\section{Saran}

Agar dapat mengetahui sejauhmana latihan keterampilan membatik dan membuat karya seni murni dan seni pakai ini berhasil, baik secara teknis maupun manfaat yang diperoleh oleh peserta, diadakan penilaian: a). Melalui uji coba menciptakan bermacammacam motif yang
Gorga : Jurnal Seni Rupa

Volume 10 Nomor 02 Juli-Desember 2021

p-ISSN: 2301-5942 | e-ISSN: 2580-2380

berorientasi pada motif ukir tradisional Minangkabauu, diawal kegiatan., b). Mewujudkan motif ukir minangkabau pada bidang gambar melalui sketsa sesuai bentuk serta fungsi kriya yang sudah dipilih., c). Memindahkan motif yang sudah terseleksi pada kain sesuai dengan desain/rancangan benda akan dibuat., d). Proses membatik dengan teknik batik tulis, mulai dari pemasangan lilin pada motif, mencolet, menembok, sampai mencelup karya yang sudah dibatik serta melorot., e). Evaluasi akhir dengan kriteria : ketepatan konsep, penguasaan bahan teknik serta kerapian dan hasil karya.

\section{DAFTAR RUJUKAN}

Khairuzzaky, K. (2018). Kajian Struktur Ragam Hias Ukiran Tradisional Minangkabau Pada Istano Basa Paguruyung. Jurnal Titik Imaji, 1(1), 5467.

Prasetya, L. E., \& Adi, S. M. (2011). Makna dan Filosofi Ragam Hias Pada Rumah Tradisional Minangkabau di Nagari Pariangan Tanah Datar. In Seminar Nasional "Kearifan Lokal Dalam Keberagaman Untuk Pembangunan Indonesia (pp. 59-70). 